\title{
Apoptosis-based dual molecular targeting by INNO-406, a second-generation Bcr-Abl inhibitor, and ABT-737, an inhibitor of antiapoptotic Bcl-2 proteins, against Bcr-Abl-positive leukemia
}

\author{
J Kuroda', S Kimura ${ }^{\star, 2}$, A Strasser ${ }^{3}$, M Andreeff ${ }^{4}$, LA O'Reilly ${ }^{3}$, E Ashihara ${ }^{2}$, Y Kamitsuji ${ }^{2,5}$, A Yokota ${ }^{2}$, E Kawata ${ }^{2,5}$, M Takeuchi $^{2,6}$,

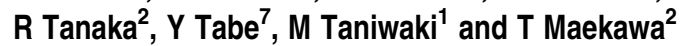

$\mathrm{Bcr}-\mathrm{Abl}$ is the cause of Philadelphia-positive $\left(\mathrm{Ph}^{+}\right)$leukemias and also constitutes their principal therapeutic target, as exemplified by dramatic effects of imatinib mesylate. However, mono-targeting of Bcr-Abl does not always achieve complete leukemia eradication, and additional strategies those enable complete elimination of leukemic cells are desired to develop. Here we demonstrate that INNO-406, a much more active Bcr-Abl tyrosine kinase inhibitor than imatinib, augments the activities of several proapoptotic $\mathrm{Bcl}-2$ homology (BH)3-only proteins (Bim, Bad, Bmf and Bik) and induces apoptosis in $\mathrm{Ph}^{+}$leukemia cells via $\mathrm{Bcl}-2$ family-regulated intrinsic apoptosis pathway. $\mathrm{ABT}-737$, an inhibitor of antiapoptotic $\mathrm{Bcl}-2$ and $\mathrm{Bcl}-\mathrm{X}_{\mathrm{L}}$, greatly enhanced the apoptosis by INNO-406, even in INNO-406-less sensitive cells with Bcr-Abl point mutations except T315I mutation. In contrast, co-treatment with INNO-406 and other pharmacologic inducers of those BH3-only proteins, such as 17-allylaminogeldanamycin, an heat shock protein-90 inhibitor, or PS-341, a proteasome inhibitor, did not further increase the BH3-only protein levels or sensitize leukemic cells to INNO-406-induced apoptosis, suggesting a limit to how much expression levels of BH3-only proteins can be increased by anticancer agents. Thus, double-barrelled molecular targeting for Bcr-Abl-driven oncogenic signaling and the cell protection by antiapoptotic Bcl-2 family proteins may be the rational therapeutic approach for eradicating $\mathrm{Ph}^{+}$leukemic cells.

Cell Death and Differentiation (2007) 14, 1667-1677; doi:10.1038/sj.cdd.4402168; published online 18 May 2007

The treatment of Philadelphia chromosome-positive $\left(\mathrm{Ph}^{+}\right)$ leukemias has improved markedly owing to the development of inhibitors of Bcr-Abl tyrosine kinase (TK). The first member of such inhibitors is imatinib mesylate (imatinib). However, resistance to imatinib can develop by various molecular mechanisms, such as Bcr-Abl overexpression, mutations within the imatinib-binding site of Bcr-Abl, expression of a drug efflux pump or compensatory overexpression of related Src family kinases. In particular, point mutations in bcr-abl constitute the most commonly occurring and intractable. ${ }^{1-4}$ It is anticipated that these resistance mechanisms can be overcome by developing more potent Bcr-Abl inhibitors that possess higher affinity for Bcr-Abl and are active against imatinib-insensitive mutated Bcr-Abl proteins. As a result, several 'second-generation' Bcr-Abl inhibitors, including dasatinib and nilotinib, have been developed. ${ }^{5,6}$ We have developed INNO-406 (formerly NS-187), which blocks BcrAbl autophosphorylation in vitro 25- to 55-fold more efficiently than imatinib and is at least 10 times more effective than imatinib in suppressing the growth of Bcr-Abl-positive (Bcr$\mathrm{Abl}^{+}$) leukemic tumors in vivo. Moreover, INNO-406 inhibits the TK activities of most of the imatinib-resistant-mutated Bcr-Abl proteins except T315I mutant. ${ }^{7,8}$

However, it appears that a few leukemic cells often survive exposure to imatinib or second-generation Bcr-Abl inhibitors. ${ }^{9,10}$ Indeed, mathematical modeling studies suggest that complete eradication of $\mathrm{Bcr}-\mathrm{Abl}{ }^{+}$leukemic cells may require simultaneous targeting of other vital molecules. ${ }^{11,12}$ Here, we have sought to identify additional therapeutic targets by characterizing the molecular mechanism by which the blockade of Bcr-Abl signaling kills $\mathrm{Ph}^{+}$leukemia cells. Our study reveals that INNO-406-induced cell death is regulated

\footnotetext{
${ }^{1}$ Division of Hematology and Oncology, Department of Medicine, Kyoto Prefectural University of Medicine, Kamigyo-ku, Kyoto, Japan; ${ }^{2}$ Department of Transfusion Medicine and Cell Therapy, Kyoto University Hospital, Kawahara-cho, Sakyo-ku, Kyoto, Japan; ${ }^{3}$ Molecular Genetics of Cancer Division, The Walter and Eliza Hall Institute of Medical Research, Parkville, Victoria, Australia; ${ }^{4}$ Department of Stem Cell Transplantation and Cellular Therapy, The University of Texas, M.D. Anderson Cancer Center, Houston, TX, USA; ${ }^{5}$ Department of Inflammation and Immunology, Graduate School of Medical Science, Kyoto Prefectural University of Medicine, Kamigyo-ku, Kyoto, Japan; ' Department of Gasteroenterology and Hematology, Shiga University of Medical Science, Seta Tsukinowa-cho, Otsu, Japan and ${ }^{7}$ Department of Clinical Pathology, Juntendo University School of Medicine, Bunkyo-ku, Tokyo, Japan

*Corresponding author: S Kimura, Department of Transfusion Medicine and Cell Therapy, Kyoto University Hospital, 54 Kawahara, Sakyo-ku, Kyoto 606-8507, Japan, Tel: + 8175751 3630; Fax: + 8175751 3631; E-mail: shkimu@kuhp.kyoto-u.ac.jp

Keywords: ABT-737; apoptosis; Bcl-2 family; Bcr-Abl; CML; INNO-406

Abbreviations: $\mathrm{Ab}$, antibody; $\mathrm{BH}, \mathrm{Bcl}-2$ homology; $\mathrm{CML}$, chronic myeloid leukemia; DN, dominant negative; ECL, enhanced chemiluminescence; ER, endoplasmic reticulumn; FADD, Fas-associated death domain; FLC(s), fetal liver cell(s); HSP-90, heat shock protein-90; imatinib, imatinib mesylate; Ph, Philadelphia; PI, propidium iodide; SDS-PAGE, sodium dodecyl sulphate-polyaclylamide gel electophoresis; TK, tyrosine kinase; wt, wild type; 17-AAG, 17-allylaminogeldanamycin

Received 18.1.07; revised 16.4.07; accepted 17.4.07; Edited by C Borner; published online 18.5.07
} 
by the interplay of pro- and antiapoptotic $\mathrm{Bcl}-2$ family proteins that share one to four ' $\mathrm{Bcl}-2$ homology domains $(\mathrm{BH} 1,2,3$ and $\mathrm{BH} 4)^{\prime}$. Of particular importance are the $\mathrm{BH} 3-$ only proteins, which are a subgroup of proapoptotic $\mathrm{Bcl}-2$ proteins that share only $\mathrm{BH} 3$ region and are essential for initiating apoptosis. ${ }^{13,14}$ As we found that several BH3-only proteins, Bim, Bad, Bmf and Bik, play essential roles in INNO-406-induced apoptosis, we assessed whether co-treatment with a drug that activates these BH3-only proteins would enhance the killing of Bcr$\mathrm{Abl}^{+}$leukemia cells by INNO-406. The drugs tested included 17-allylaminogeldanamycin (17-AAG), a heat shock protein (HSP)-90 inhibitor and PS-341, a proteasome inhibitor; both have previously been shown to elevate Bim, Bad, Bmf or Bik expression. ${ }^{15-18}$ We also examined whether the killing of INNO-406 could be enhanced by co-treatment with ABT-737, a drug that decreases the antiapoptotic barrier imposed by the antiapoptotic Bcl-2 family members Bcl-2, Bcl- $\mathrm{X}_{\mathrm{L}}$ and $\mathrm{Bcl}-\mathrm{w} .{ }^{19,20}$ Our study shows that simultaneously targeting both pro- and antiapoptotic molecules augments the killing achieved with INNO-406, even in Bcr-Abl ${ }^{+}$leukemias bearing imatinib-resistant Bcr-Abl point mutations. Notably, like $\mathrm{Ph}^{+}$ leukemias, most cancers maintain and propagate themselves by resisting apoptosis and enhancing cell proliferation. Inhibition of signaling for cell proliferation causes the cell cycle arrest as well as the initiation of apoptotic cell death. Thus, a double-barrelled therapeutic strategy like the one described here that targets both apoptosis resistance and enhanced proliferation of tumor cells may also be suitable for other cancers.

\section{Results}

INNO-406 induces apoptosis in Bcr-Abl ${ }^{+}$leukemias. We first confirmed that INNO-406 kills Bcr-Abl ${ }^{+}$cells by treating the chronic myeloid leukemia (CML)-derived cell lines $\mathrm{K} 562$, BV173 and MYL and bcr-abl-transformed wild-type (wt) murine fetal liver-derived myeloid progenitor cells (wt bcr$a b l^{+}$FLCs) with this drug (Figure 1a, d and data not shown). As INNO-406 caused DNA fragmentation in all four lines, it appears to induce apoptosis (Figure $1 \mathrm{~b}$ and data not shown). To identify the apoptotic pathway that is stimulated by INNO406 , we examined the effect of INNO-406 on genetically engineered $\mathrm{K} 562$ subclones that overexpressed human $\mathrm{Bcl}-2$ (K562/Bcl-2) or a dominant-interfering mutant of Fasassociated death domain (FADD)/MORT1 (K562/FADD-DN), which inhibits death receptor-induced apoptosis; both molecules were labeled with an N-terminal Flag tag (Figure 1c). ${ }^{21-23} \mathrm{We}$ found that $\mathrm{Bcl}-2$ overexpression blocked INNO-406-induced K562 cell death, whereas FADD-DN had no effect. Moreover, BV173R, a subclone of BV173, which expresses higher levels of Bcl-2 than parental BV173 cells, was less sensitive to INNO-406-induced cell death than BV173 (Figure 1c, d). These results demonstrate that INNO-406 induces apoptosis of $\mathrm{Bcr}^{-\mathrm{Abl}}{ }^{+}$cells via the $\mathrm{Bcl}-2$ family-regulated intrinsic apoptotic pathway.

Recently, Bim, a member of the proapoptotic BH3-only subgroup of the Bcl-2 family, was found to participate in imatinib-induced apoptosis of $\mathrm{Ph}^{+}$leukemia cells. ${ }^{15,22,24}$ Importantly, we found that the K562/short hairpin (sh) Bim subline, in which Bim expression is repressed by RNA interference (RNAi), was more resistant to INNO-406 than parental K562. However, K562/shBim cells were not as resistant to INNO-406 as K562 cells overexpressing Bcl-2, indicating that other proapoptotic proteins cooperate with Bim. Notably, BV173R/shBim cells were more resistant to INNO406-induced cell death than BV173R cells (Figure 1c, d), demonstrating that Bim knockdown and $\mathrm{Bcl}-2$ overexpression can cooperate to render Bcr-Abl ${ }^{+}$cells resistant to INNO-406. This suggests that simultaneously targeting the Bim-mediated pathway via INNO-406 and inhibiting pro-survival Bcl-2 and some of its homologues may improve the efficacy of therapies against $\mathrm{Ph}^{+}$leukemia.

Effect of INNO-406 on the expression of BH3-only proteins. To characterize further the pathway by which INNO-406 induces apoptosis, we examined the effects of this drug on mechanisms that regulate the activity of Bim and the other BH3-only family proteins, including Bad, Bik, Bmf, Hrk, Noxa and Puma. BH3-only proteins are regulated by a range of transcriptional and post-translational mechanisms. ${ }^{25}$ We therefore first examined the effect of INNO-406 on the transcription of $\mathrm{BH} 3-$ only genes in $\mathrm{K} 562, \mathrm{~K} 562 / \mathrm{Bcl}-2$ and K562/shBim cells. INNO-406 elevated bim mRNA levels in $\mathrm{K} 562$ and $\mathrm{K} 562 / \mathrm{Bcl}-2$ cells. In the $\mathrm{K} 562 / \mathrm{shBim}$ cells, the RNAi reduced basal bim mRNA levels to about half of those seen in parental $\mathrm{K} 562$ and $\mathrm{K} 562 / \mathrm{Bcl}-2$ cells, but treatment with INNO-406 still slightly increased bim mRNA levels, albeit to a lesser extent compared with parental K562 cells. bad mRNA was readily detectable in all K562 subclones and treatment with INNO-406 did not affect this (Figure 2a). In contrast, the basal levels of bmf and bik mRNA were very low in all K562 subclones, but treatment with INNO-406 significantly increased their levels (Figure 2b). INNO-406 did not cause any changes in the levels of hrk, noxa or puma expression (data not shown). Thus, INNO-406 upregulates the transcription of bim, bmf and bik, but not bad, hrk, noxa or puma.

Next, we examined the effects of INNO-406 on the expression of Bim, Bad, Bmf, Bik, Puma and Noxa protein.

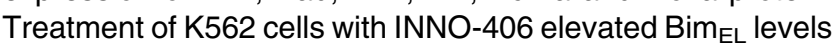
within $6 \mathrm{~h}$ and also increased its mobility on sodium dodecyl sulfate-polyaclylamide gel electophoresis (SDS-PAGE), which is a hallmark of the dephosphorylation that is known to activate Bim. ${ }^{22,26}$ Treatment with INNO-406 also increased the levels of Bmf and Bik. Although INNO-406 did not change the overall levels of Bad, it induced Bad dephosphorylation (Figure 2c). These findings were also the cases with bcr-abltransformed FLCs. Within $6 \mathrm{~h}$, the levels and migration speed of Bim $\mathrm{EL}_{\mathrm{L}}$ increased, Bad became dephosphorylated, and the levels of Bmf and to low extent also those of Bik increased (Figure 2d). In contrast, Puma or Noxa protein was not increased, but decreased, after INNO-406 treatment (Supplementary Figure 1).

Loss of Bim, Bad or Bmf partially inhibits INNO-406induced apoptosis of Bcr-Abl-transformed murine FLC. The mechanisms of INNO-406-induced apoptosis were further examined by comparing bcr-abl transformed FLCs from $w t, b c l-2$ transgenic, $b i m^{-1-}, b a d^{-1}, b m f^{-1-}$ or 

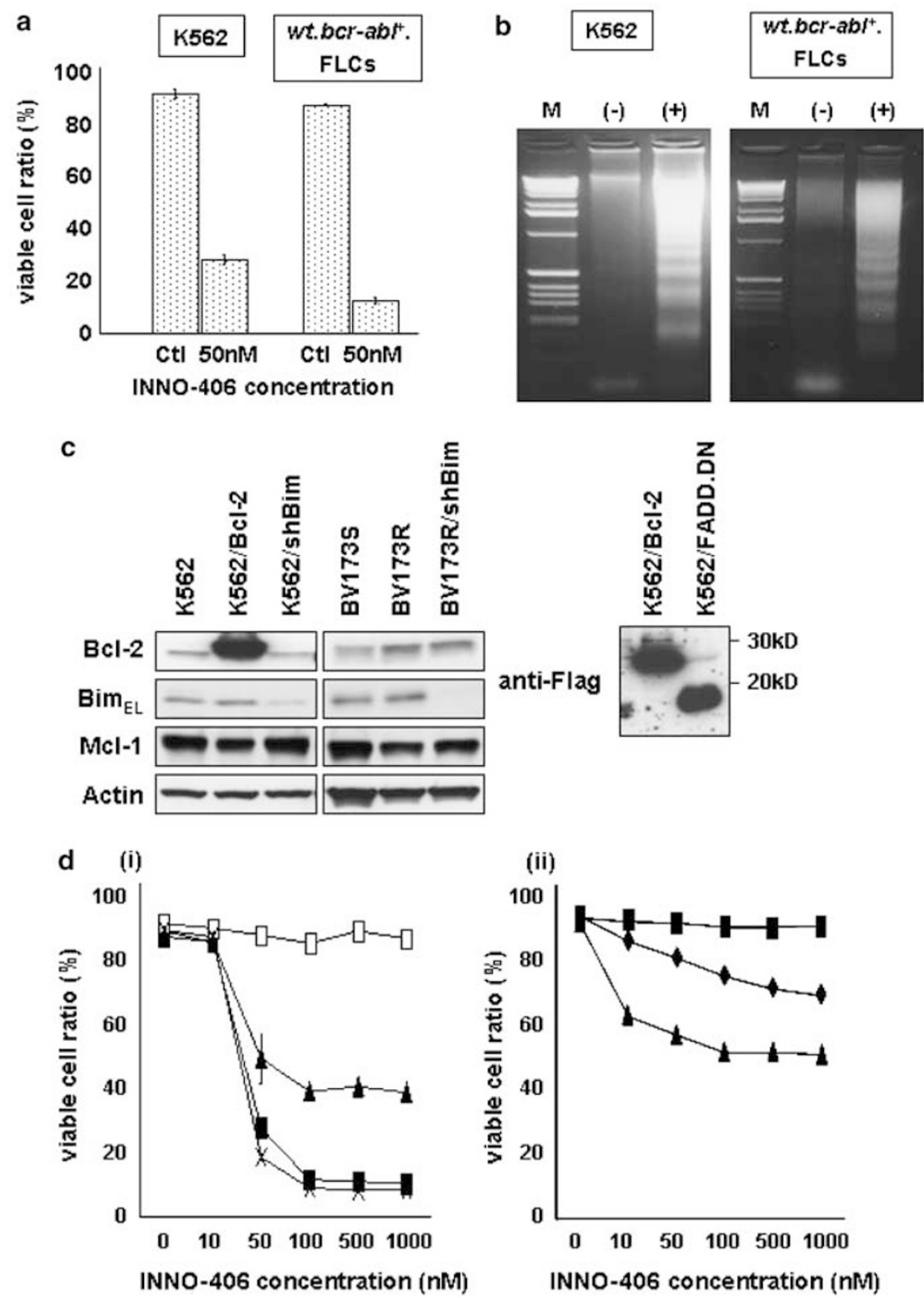

Figure 1 INNO-406 kills bcr-ab/ transformed cells via the intrinsic apoptotic pathway. (a) Survival of K562 and bcr-ab/ transformed wt FLC after 48 or $24 \mathrm{~h}$ treatment with $50 \mathrm{nM}$ INNO-406, respectively. Viable cell ratio was measured by flow cytometric analysis for the uptake of PI. (b) DNA fragmentation in K562 or bcr-ab/ transformed wt FLC

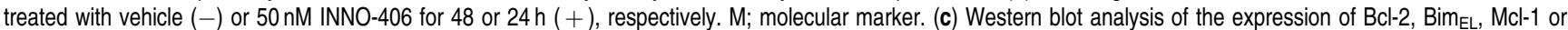
transgenic Flag-tagged Bcl-2 or FADD-DN proteins in K562 or BV173 cells and their subclones. (d) Survival of (i) K562/Bcl-2 (open square $\square$ ), K562/shBim (triangle $\mathbf{\Delta}$ ), K562/ FADD.DN (cross $\times$ ) and parental K562 cells (closed square $\mathbf{\square}$ ), as well as (ii) BV173R/shBim (closed square $\mathbf{\square}$ ), BV173R (closed diamond ) and parental BV173 cells (triangle $\mathbf{\Lambda}$ ) after $48 \mathrm{~h}$ treatment with INNO-406

bim $^{-1-}$ bad $^{-1-}$ embryos. As shown in Figure 3, most bcr-abl transformed wt FLCs had died within $48 \mathrm{~h}$ exposure to $>50 \mathrm{nM}$ INNO-406. In contrast, the bcl-2 transgenic FLCs (vav.bcl-2 transgenic ${ }^{+} b c r-a b l^{+}$.FLCs) were highly resistant, whereas the $\mathrm{bim}^{-1-}$ and to a lesser extent also the $\mathrm{bad}^{-1-}$ and $b m f^{-1-} . b c r-a b l^{+}$. FLCs showed partial resistance. The $b i m^{-1-} b a d^{-1-} . b c r-a b l^{+}$. FLCs were more resistant to INNO-406-induced cell death than the $\mathrm{bim}^{-/}$or the $\mathrm{bad}^{-/}$. $b c r-a b l^{+}$.FLCs, but not as much as vav.bcl-2 transgenic ${ }^{+}$ $b c r-a b l^{+}$.FLCs. These results suggest that these three $\mathrm{BH} 3-$ only proteins, Bim, Bad and Bmf, have overlapping functions in INNO-406-induced apoptosis.

17-AAG does not enhance INNO-406-induced killing of $\mathrm{Bcr}^{-A \mathrm{Al}^{+}}$leukemia cells. 17-AAG inhibits Bcr-Abl signaling by a different mechanism to that used by INNO406, namely, 17-AAG inhibits the HSP-90 chaperone protein and thereby promotes the degradation of its client Bcr-Abl protein (Figure 4a). ${ }^{16}$ Notably, Akt, a major downstream signaling molecule of Bcr-Abl that regulates the expression of 

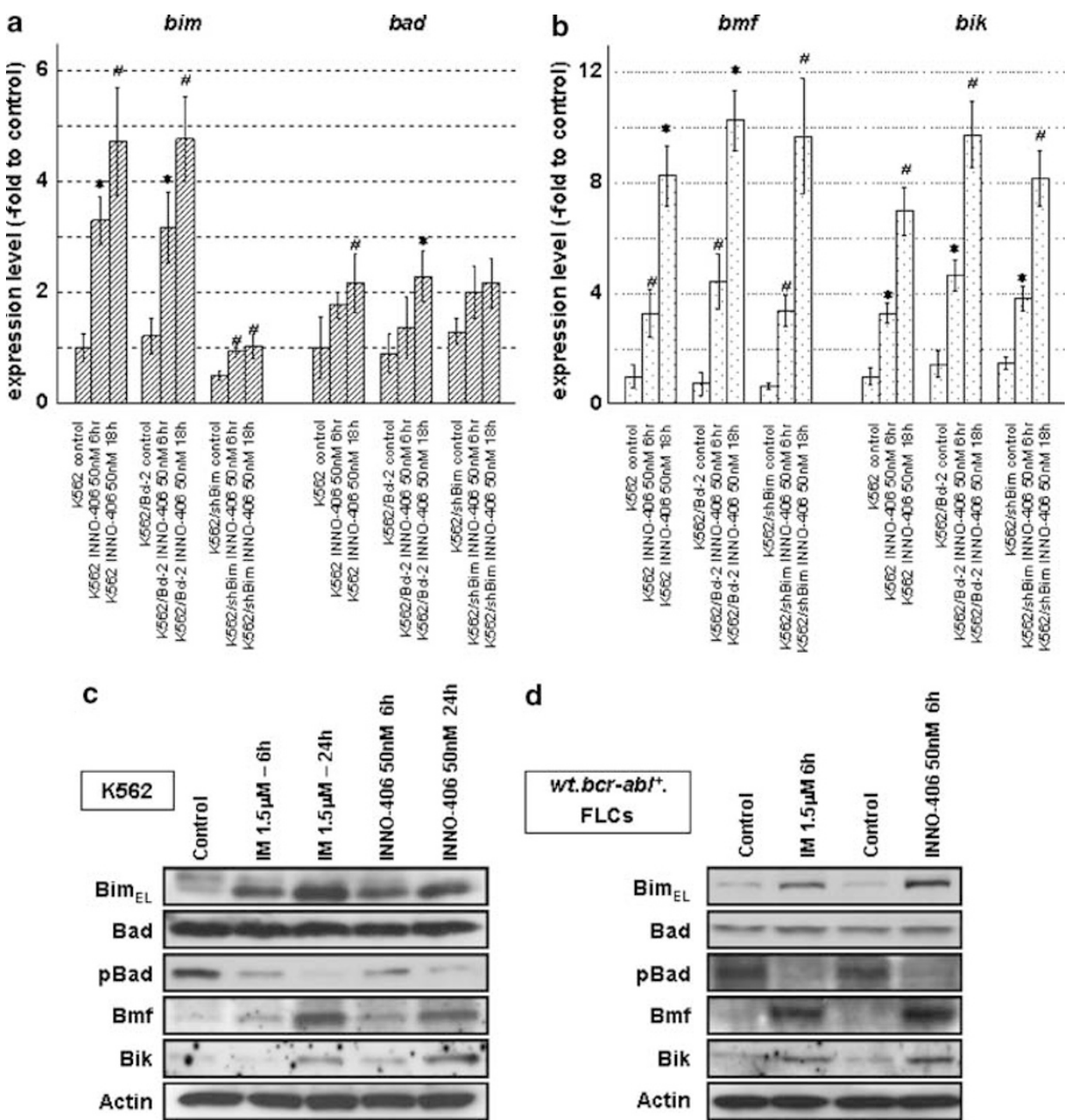

Figure 2 Treatment with INNO-406 elevates levels of bim, bmf and bik mRNA and the corresponding proteins, and causes dephosphorylation of Bim and Bad. (a, b) Effect of 6 or $18 \mathrm{~h}$ treatment with $50 \mathrm{nM} \mathrm{INNO}-406$ on the mRNA levels of bim and bad (a) and bmf and bik (b) in K562, K562/Bcl-2 and K562/shBim cells. ${ }^{*} P<.05$ and ${ }^{*} P<.005$ for untreated control. (c, d) Effect of $1.5 \mu \mathrm{M}$ imatinib (IM) or $50 \mathrm{nM}$ INNO-406 treatment on the BH3-only protein levels in $\mathrm{K} 562$ (c) and wt.bcr-abl ${ }^{+}$. FLCs (d), as measured by Westem blotting analysis

Bim and Bad, is also known to be a client of HSP-90. ${ }^{27}$ Thus, 17-AAG may restore the Bim and Bad levels and their proapoptotic activity in bcr-abl-expressing cells. Indeed, treatment of K562 and BV173 cells with 17-AAG caused an increase in the levels of Bim, Bmf and Bik, Bad dephosphorylation and a faint reduction in the levels of antiapoptotic Mcl-1 (Figure 4b, c). 17-AAG caused a dosedependent apoptosis over $48 \mathrm{~h}$ that plateaued around $0.5 \mu \mathrm{M}$ and the apoptosis by 17-AAG was partially inhibited by Bim knockdown and almost entirely blocked by Bcl-2 overexpression. Contrary to our expectation, co-treatment with 17-AAG did not augment INNO-406-induced killing of K562 or BV173 cells (Figure 5a, Supplementary Figure 2a), and the two agents together cannot enhance the activation of these $\mathrm{BH} 3$-only proteins further (Figure $4 \mathrm{~b}$ ).

Effect of combined treatment or Bcr-AbI ${ }^{+}$cells with INNO-406 and PS-341. Even though PS-341 treatment did not affect $\mathrm{Bcl}-2$ or $\mathrm{Bcl}-\mathrm{X}_{\mathrm{L}}$ level, but accumulated $\mathrm{Mcl}-1$ in K562 cells, it elevated caspase-8 activity (Figure 4a,c,d). This indicates that it operates by a pathway that differs from

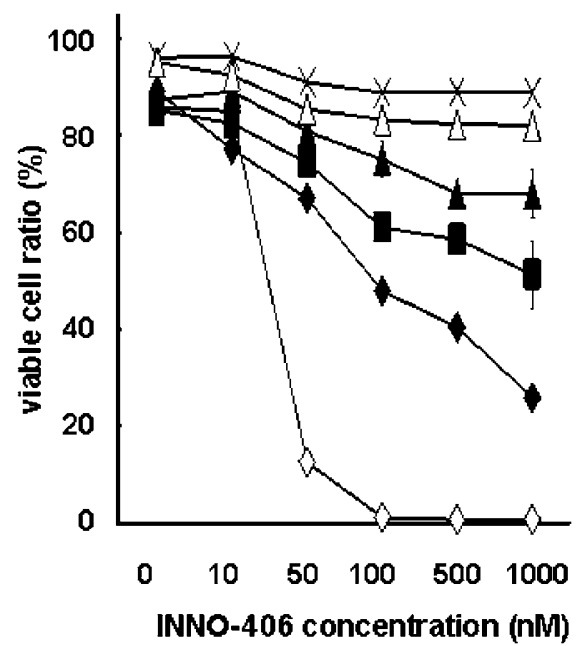

Figure 3 Cell killing effects of INNO-406 are represented by viable cell ratio after 48-h treatment of wt.bcr-abl ${ }^{+}$. FLCs (open diamond $\left.\diamond\right)$, bim $^{-1} . b c r-$ $a b l^{+}$. FLCs (closed triangle $\mathbf{\Lambda}$ ), bad ${ }^{-1} . b c r-a b l^{+}$.FLCs (square $\mathbf{\square}$ ), bmf ${ }^{-1-} . b c r-$ $a b l^{+}$.FLCs (diamond ), $b i m^{-1-} b a d^{-/-} . b c r-a b l^{+}$.FLCs (open triangle $\triangle$ ) and vav.bcl-2 transgenic $\left.{ }^{+} b c r-a b\right)^{+}$.FLCs (cross $\left.x\right)$ 
a
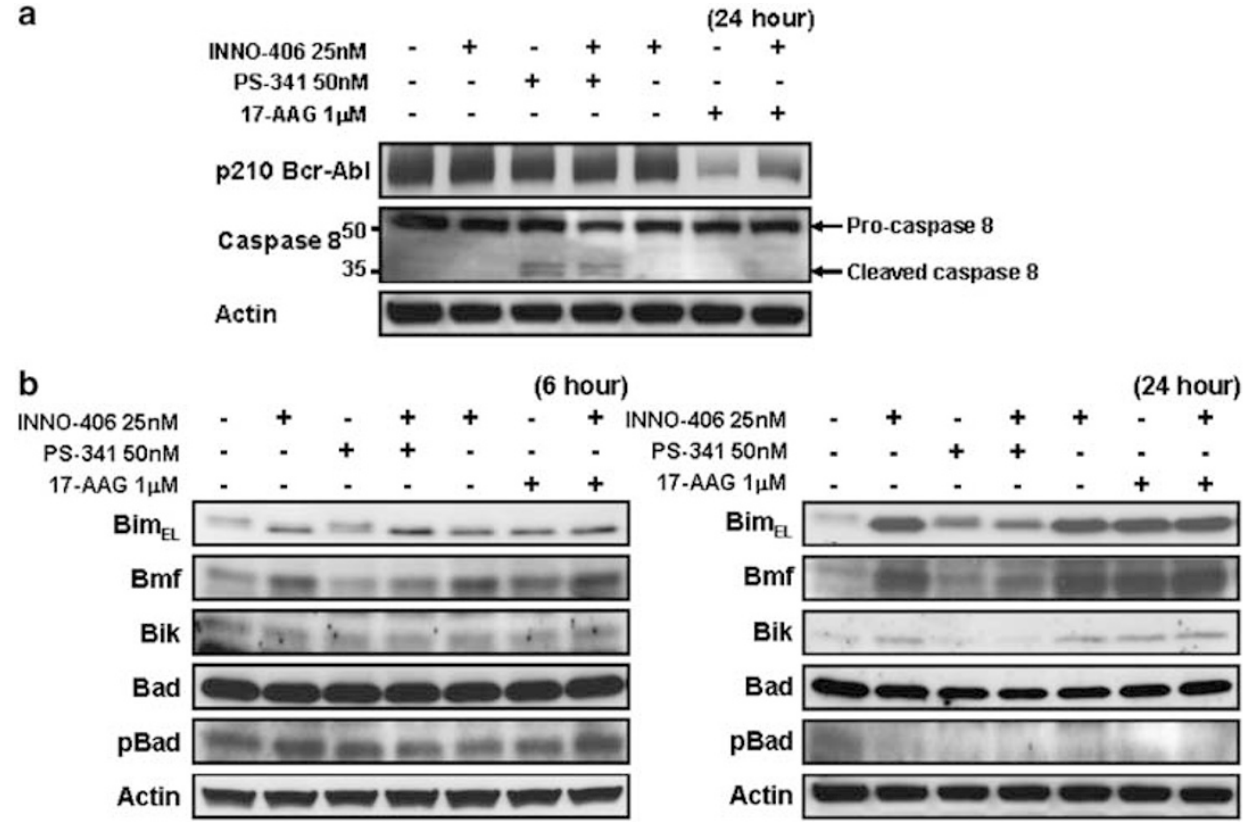

c

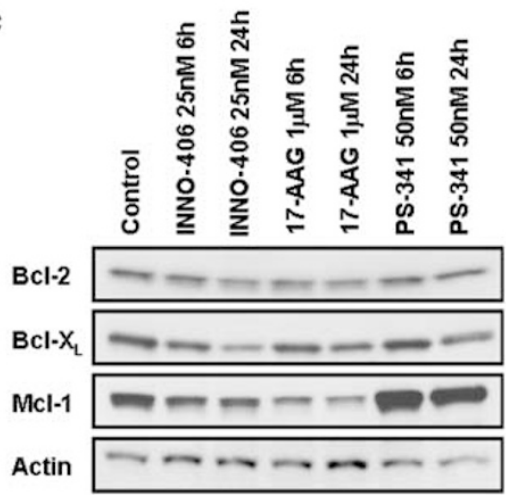

d

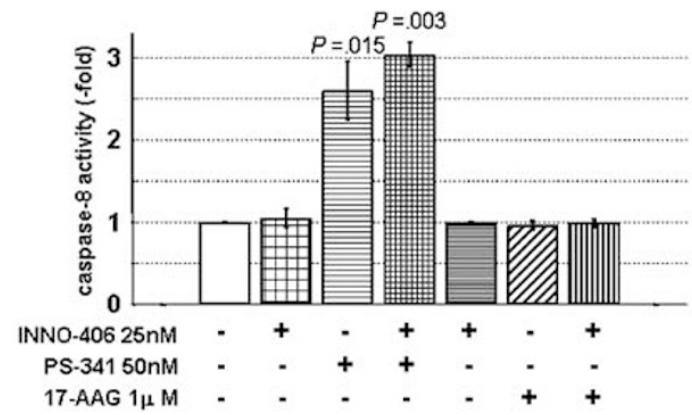

Figure 4 Effect of PS-341 or 17-AAG co-treatment with INNO-406 on caspase-8 activity and p210 Bcr-Abl, caspase-8 and BH3-only protein levels. K562 cells were treated for $24 \mathrm{~h}$. (a, b) p210 Bcr-Abl, caspase-8 (a) and BH3-only protein (b) levels were determined by Western blot analysis. (c) Effect of 6 or $24 \mathrm{~h}$ treatment with INNO-406 (25 nM), 17-AAG $(1 \mu \mathrm{M})$ or PS-341 $(50 \mathrm{nM})$ on the expression of Bcl-2, Bcl- $\mathrm{X}_{\mathrm{L}}$ and Mcl-1 in K562 cells. (d) Caspase-8 activity by INNO-406, PS-341, 17-AAG or their combinations

intrinsic apoptosis. PS-341 also increased Bim levels but did not affect Bmf or Bik levels or promote Bad dephosphorylation, and its combination with INNO-406 did not further elevate the Bim levels in K562 cells (Figure 4b). PS-341 killed K562 and BV173 in a dose-dependent manner and was unaffected by $\mathrm{Bcl}-2$ overexpression or Bim knockdown. When combined, PS-341 and INNO-406 killed parental and Bim-knockdown K562 cells and BV173 cells more effectively than either drug alone. Moreover, when INNO-406-induced apoptosis was blocked by $\mathrm{Bcl}-2$ overexpression, PS-341 retained its killing effect (Figure 5b, Supplementary Figure 2b). Thus, PS-341 and INNO-406 kill Bcr-Abl ${ }^{+}$cells via different apoptotic mechanisms and can act cooperatively.

ABT-737 dramatically augments INNO-406-induced cell death and overcomes the INNO-406 resistance imparted by $\mathrm{Bcl}-2$ overexpression or Bim knockdown. ABT-737 is a $\mathrm{BH} 3-$ mimic that inhibits the activity of the antiapoptotic
$\mathrm{Bcl}-2, \mathrm{Bcl}-\mathrm{X}_{\mathrm{L}}$ and $\mathrm{Bcl}-\mathrm{w}$ proteins, but not $\mathrm{Mcl}-1$, and has been reported to augment the cell killing effects of genotoxic treatments in hematologic malignancies and lung cancers. $^{19,20}$ As INNO-406 activates several BH3-only proteins and slightly reduces Mcl-1 (Figure 2, 4c), we expected the complementary apoptosis enhancing effect between INNO-406 and ABT-737. ABT-737 killed K562, BV173 and MYL cells in a dose-dependent manner and this was not strongly impeded by Bim knockdown or Bcl-2 overexpression. Significantly, ABT-737 strongly augmented the INNO-406-induced apoptosis of K562, BV173 and MYL cells. Notably, ABT-737 restored the sensitivity of $\mathrm{K} 562 / \mathrm{shBim}$ or $\mathrm{K} 562 / \mathrm{Bcl}-2$ to INNO-406-induced cell death (Figure 5c, Supplementary Figure 2c, 3b).

Cells expressing mutant $\mathrm{Bcr}-\left.\mathrm{Abl}\right|^{\mathrm{E} 255 \mathrm{~K}}$ or $\mathrm{Bcr}-\left.\mathrm{Abl}\right|^{\mathrm{H} 396 \mathrm{P}}$ but not $\mathrm{Bcr}-\mathrm{AbI}{ }^{\mathrm{T3151}}$ develop sensitivity to INNO-406 upon co-treatment with ABT-737. Although INNO-406 can inhibit the TK activities of most imatinib-resistant Bcr-Abl 

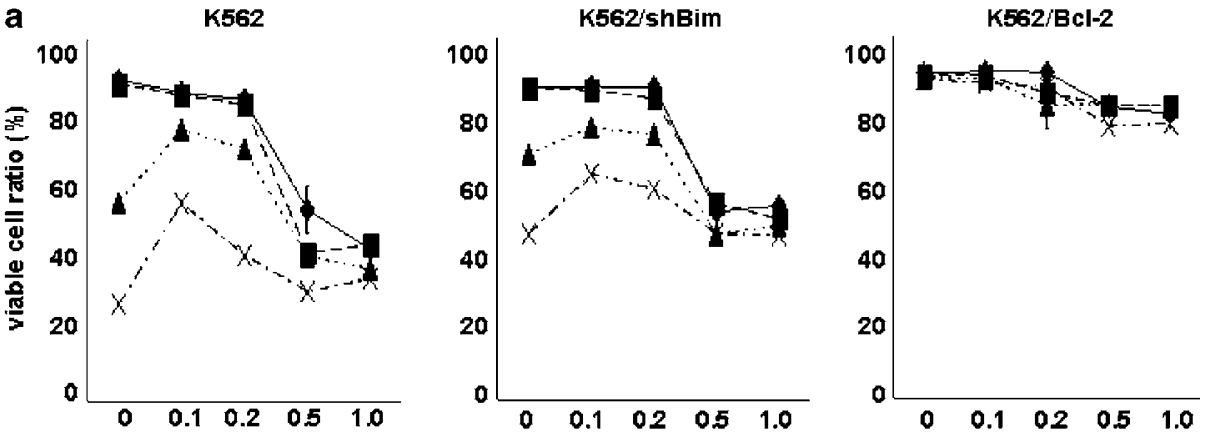

$17-\mathrm{AAG}$ concentration $(\mu \mathrm{M})$

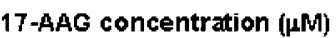

17-AAG concentration $(\mu \mathrm{M})$
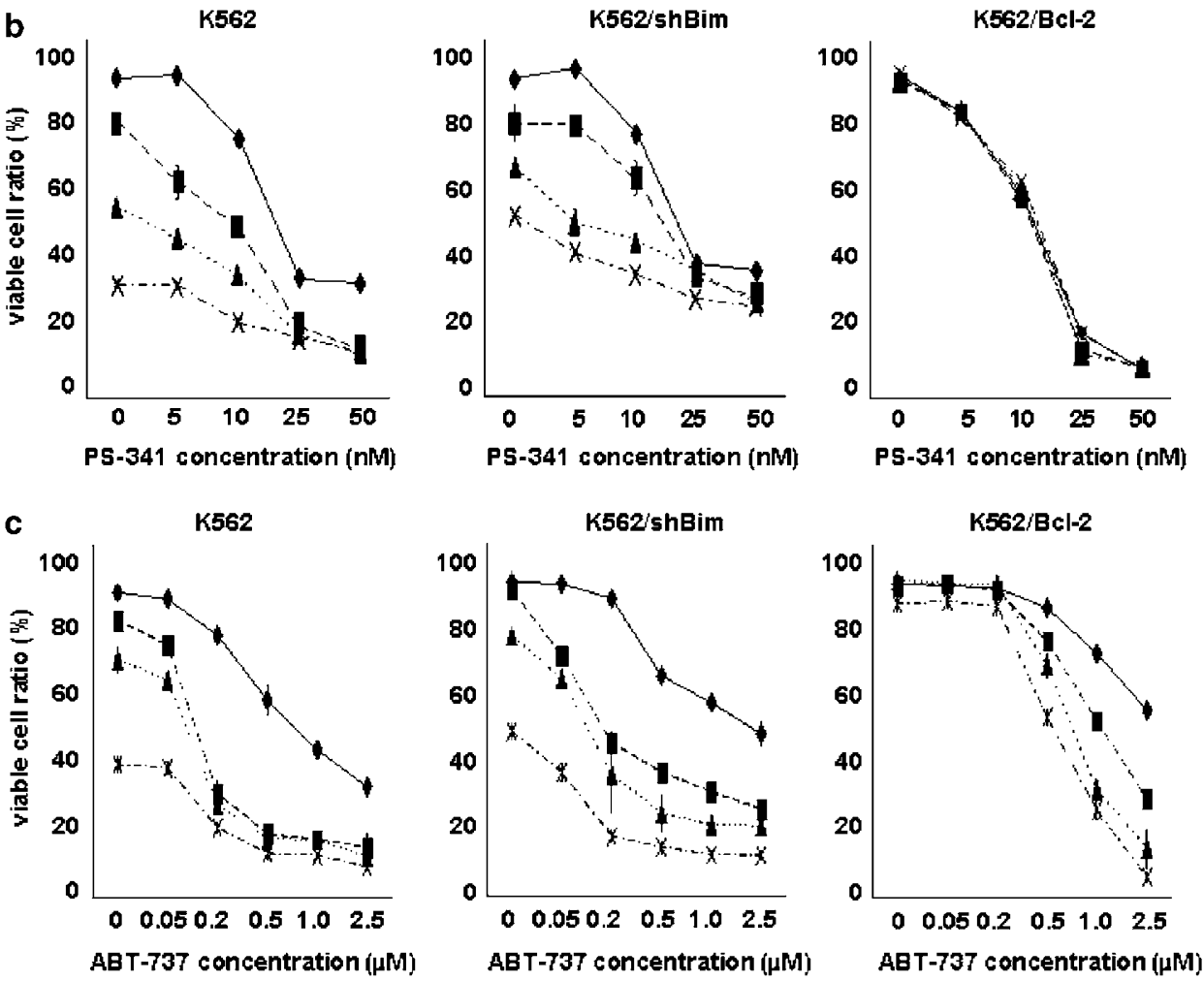

Figure 5 ABT-737 effectively augments INNO-406 in killing bcr-ab/transformed cells. K562, K562/shBim and K562/Bcl-2 cells were treated with (a) 17-AAG, (b) PS-341 or (c) ABT-737 alone (vehicle (diamond ) or together with $5 \mathrm{nM}$ (square $\mathbf{-}$ ), $10 \mathrm{nM}$ (triangle $\mathbf{A}$ ) or $25 \mathrm{nM}$ (cross $\times$ ) INNO-406. The percentages of viable cells after $48 \mathrm{~h}$ of treatment are shown

mutants, such as Bcr-Abl ${ }^{\mathrm{E} 255 \mathrm{~K}}$ or $\mathrm{Bcr}-\mathrm{Abl}{ }^{\mathrm{H} 396 \mathrm{P}}$, much higher concentrations are needed to kill cells expressing these mutants than are needed for killing cells containing wt Bcr-Abl. ${ }^{7}$ Thus, we examined whether lowering of the antiapoptotic barricade by treatment with ABT-737 could restore the ability of INNO-406 to kill leukemic cells bearing imatinib-resistant Bcr-Abl. For this, we generated Ba/F3derived murine hematopoietic cell lines transformed with wt p210-Bcr-Abl (Ba/F3/wt bcr-abl) or Bcr-Abl bearing the E255K (Ba/F3/E255K), T315I (Ba/F3/T315I) or the H396P mutation $(\mathrm{Ba} / \mathrm{F} 3 / \mathrm{H} 396 \mathrm{P})$. The T315I mutation abolishes binding by both imatinib as well as INNO-406 and cells bearing this mutation are therefore completely resistant to both compounds. When the four $\mathrm{Ba} / \mathrm{F} 3$ lines were treated with INNO-406, those with the E255K and H396P mutations were clearly less sensitive than $\mathrm{Ba} / \mathrm{F} 3 / \mathrm{wt}$ bcr-abl cells: $500 \mathrm{nM}$ INNO-406 elicited $>90 \%$ death of Ba/F3/wt. bcr-abl cells but only $\sim 20 \%$ killing of $\mathrm{Ba} / \mathrm{F} 3$ lines expressing mutant Bcr-Abl. Ba/F3/T315l bcr-ab/ cells were completely resistant to INNO-406 (Figure 6b). These observations were paralleled by the effect of treatment on Bcr-Abl phosphorylation, as the wt Bcr-Abl expressing cells showed marked downregulation of Bcr-Abl phosphorylation, whereas this effect was less pronounced in cells expressing the E255K mutant and absent in those expressing the T315I mutant. As expected, INNO-406 induced much less Bim upregulation in the E255K and H396P mutant Bcr-Abl cells than in $\mathrm{Ba} / \mathrm{F} 3 / \mathrm{wt} b c r-a b /$ cells, and had no effect on the levels or phosphorylation of $\mathrm{Bim}$ in $\mathrm{Ba} / \mathrm{F} 3 / \mathrm{T} 315 \mathrm{l} b c r-a b /$ cells (Figure $6 \mathrm{a}$ and data not shown). When the cells were 
co-treated with ABT-737 and INNO-406, Ba/F3/T315I remained resistant to INNO-406 and only the killing effects of ABT-737 were observed. Significantly, however, the cells expressing the E225K and H369P Bcr-Abl mutants were killed almost as efficiently as the Ba/F3/wt bcr-abl cells (Figure $6 \mathrm{~b}$ ). Thus, ABT-737 is an ideal partner for INNO-406 in eradicating leukemic cells with Bcr-Abl mutations except T315I.

17-AAG plus ABT-737 produces more cell killing effects even in cells expressing mutant $\mathrm{Bcr}-\mathrm{Abl}{ }^{\mathrm{T} 315 \mathrm{I}}$ than either drug alone. Given that 17-AAG activates Bim, Bad, Bmf and Bik and slightly reduces $\mathrm{Mcl}-1$ through the blockade of Bcr-Abl (Figure 4b, c), we next examined whether cell death inducing effect by 17-AAG could be also enhanced by ABT737. As shown in Figure 7, the combination of these two agents produced more cell death not only in INNO-406sensitive cells (i.e. $\mathrm{Ba} / \mathrm{F} 3 / \mathrm{wt}$ bcr-abl, Ba/F3/E255K and $\mathrm{Ba} / \mathrm{F} 3 / \mathrm{H} 396 \mathrm{P}$ in this study) but also, importantly, in INNO406-insensitive leukemic cells harboring T315I mutation. These again indicate that the inhibition of antiapoptotic $\mathrm{Bcl}-2$ proteins is effective approach to augment the cell killing effect by the blockade of Bcr-Abl, and this combination could be a good alternative approach for leukemic cells insensitive to Bcr-Abl TK inhibitors.

Combination effect of INNO-406 and ABT-737 on imatinib-resistant MYL cells expressing higher level of Mcl-1. Finally, we examined the effects of INNO-406, ABT737 and their combination on imatinib-resistant MYL-R cells. MYL-R was generated by continuous exposure up to $1.0 \mu \mathrm{M}$ imatinib in culture, and was found to express higher level of $\mathrm{Mcl}-1$, whereas the levels of Bim or other $\mathrm{BH} 3-$ only proteins were not reduced (unpublished data) (Supplementary Figure 3a). ${ }^{28}$ When compared with MYL, MYL-R was resistant to cell death either by INNO-406 or ABT-737, and the cell death by INNO-406 was increased only when the higher concentration of ABT-737 was combined (Supplementary Figure $3 b, c)$.

\section{Discussion}

$\mathrm{Bcr}-\mathrm{Abl}$ is the principal molecular target against $\mathrm{Ph}^{+}$ leukemias; however, the mono-targeting of Bcr-Abl appears to be insufficient for the complete eradication. Clinically, a number of patients who achieve molecular remission upon imatinib treatment suffer disease relapse when the drug is discontinued. ${ }^{29,30}$ Furthermore, Bcr-Abl inhibitors have been shown to be more cytostatic than cytotoxic against $\mathrm{Bcr}-\mathrm{Abl}^{+}$ leukemic cells. ${ }^{9,10}$ These suggest that the complete eradication of $\mathrm{Bcr}-\mathrm{Abl}^{+}$leukemic cells may require $\mathrm{Bcr}-\mathrm{Abl}$ inhibitors in combination with therapies that modify the molecular pathways that control cell survival. Our study supports this premise, as we were able to markedly increase the killing of $\mathrm{Bcr}-\mathrm{Abl}^{+}$leukemic cells by treating cells with INNO-406 plus ABT-737, which lowers the antiapoptotic barrier. Significantly, this co-treatment regimen also overcame the partial resistance to INNO-406 of leukemic cells expressing mutant forms of Bcr-Abl, which exhibit reduced binding of TK inhibitors.

We here showed that INNO-406-induced apoptosis in Bcr$\mathrm{Abl}^{+}$leukemic cells is mediated by Bim and, perhaps to lesser extent, also other BH3-only proteins, such as Bad, Bmf and Bik. The blockade of Bcr-Abl by INNO-406 probably upregulates bim transcription through shutdown of the PI3 kinase pathway leading to activation of forkhead box O3A, a known

a
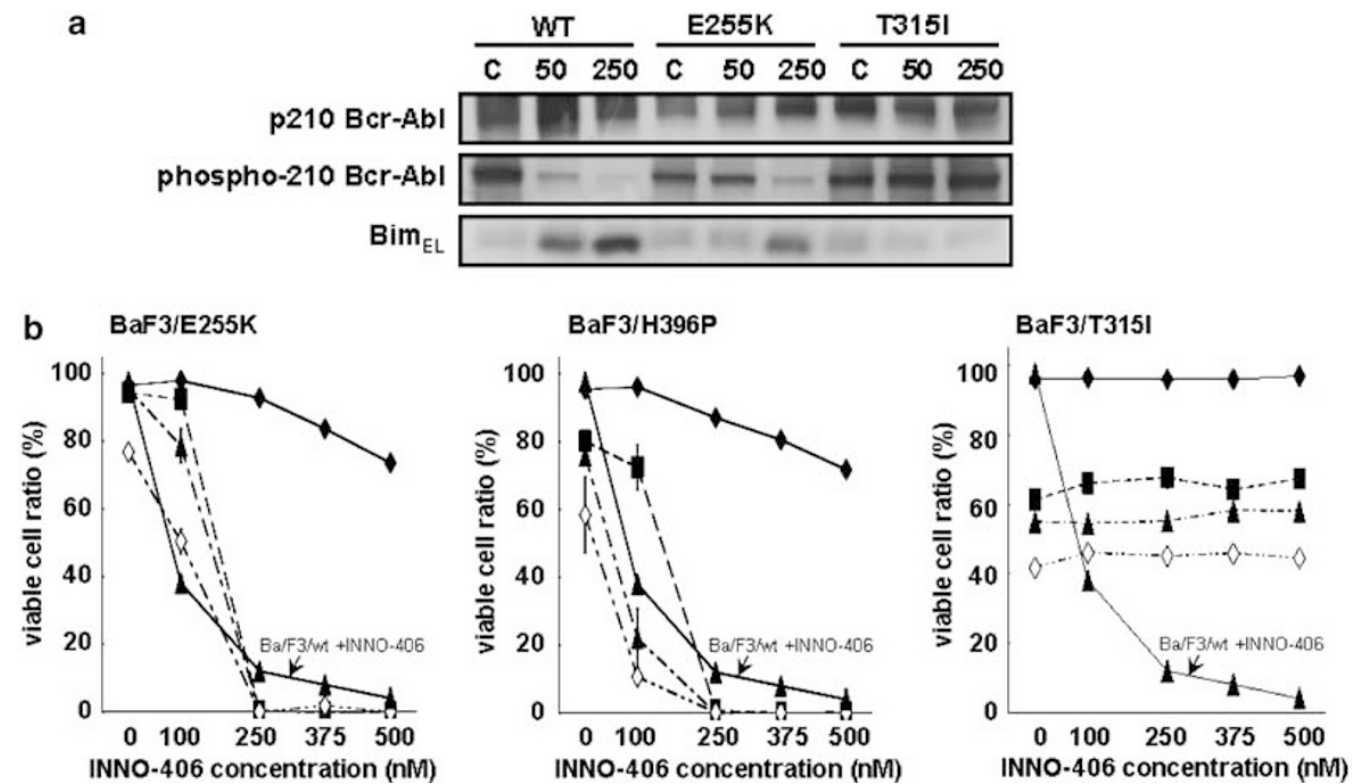

Figure 6 Co-treatment with ABT-737 and INNO-406 effectively kills cells with Bcr-Abl bearing the E225K or H369P mutation. (a) Ba/F3/wt, Ba/F3/E255K and Ba/F3/T315I were treated with 50 or $250 \mathrm{nM}$ INNO-406 or with vehicle for $12 \mathrm{~h}$, after which the p210 Bcr-Abl and Bim $\mathrm{EL}$ protein levels and the phosphorylation status of p210 Bcr-Abl were determined by Western blot analysis. (b) Ba/F3/E255K, Ba/F3/H396P and Ba/F3/T315I cells were treated with various concentrations of INNO-406 alone (vehicle (closed diamond ) or together with $2.5 \mu \mathrm{M}$ (square $\mathbf{\square}$ ), $5 \mu \mathrm{M}$ (open triangle $\triangle$ ) or $10 \mu \mathrm{M}$ (open diamond $\diamond$ ) ABT-737. The percentages of viable cells after $48 \mathrm{~h}$ of treatment are shown. The effect of INNO-406 alone on Ba/F3/wt.bcr-abl cells is indicated by arrows (closed triangles $\mathbf{\Delta}$ ) 

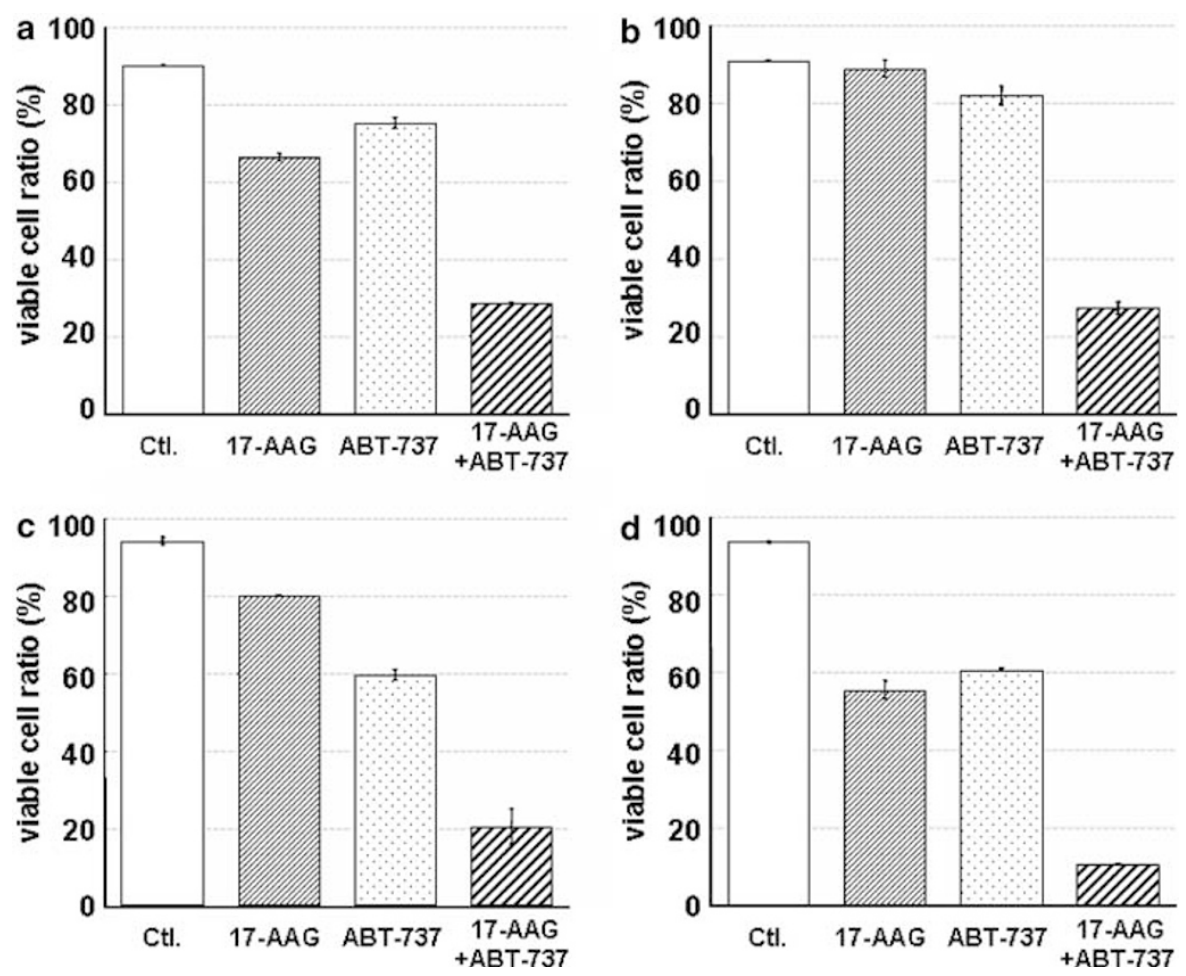

Figure 7 Combinatory cell killing effects between 17-AAG $(0.5 \mu \mathrm{M})$ and ABT-737 $(1 \mu \mathrm{M})$ for $72 \mathrm{~h}$ on (a) Ba/F3/wt.bcr-abl, (b) Ba/F3/E255K, (c) Ba/F3/H396P and (d) $\mathrm{Ba} / \mathrm{F} 3 / \mathrm{T} 315 \mathrm{l}$. Mean \pm S.D. of viable cell ratios are demonstrated by three independent experiments

transcriptional activator of bim. ${ }^{31}$ Loss of ERK $1 / 2$ or AKT kinase activity is probably responsible for de-phosphorylation and activation of Bim and Bad, respectively. ${ }^{32}$ INNO-406 induces Bmf and Bik approximately 30 -fold more potently than imatinib, but how this is achieved is presently unknown.

Based on these observations, we searched for promising agents whose combination with INNO-406 would enhance its apoptotic effect. We first tested two clinically available agents, 17-AAG and PS-341, both of which are able to increase the levels of Bim, Bad, Bmf and/or Bik in cancer cells. ${ }^{15,17,18}$ Indeed, 17-AAG potently increased Bim, Bmf and Bik expression and caused Bad dephosphorylation in Bcr-Abl ${ }^{+}$ cells, but its combination with INNO-406 did not further increase the expression of the $\mathrm{BH} 3$-only proteins or enhance cell killing. A possible explanation for this could be that there is a limit to how much expression levels of $\mathrm{BH} 3$-only proteins can be increased. Like 17-AAG, PS-341 co-treatment with INNO406 did not further elevate BH3-only protein levels, but it increased cell killing via a distinct pathway to that used by INNO-406. The cell death pathway activated by PS-341 is currently unclear. Although this drug triggered caspase-8 cleavage, a hallmark of the extrinsic apoptosis pathway, the K562/FADD.DN was only marginally resistant to PS-341 (data not shown). This suggests that PS-341-induced cell killing is unlikely to be mediated by the extrinsic apoptosis pathway. Instead, this drug may induce endoplasmic reticulum (ER) stress-mediated cell death via the unfolded protein response, ${ }^{33}$ although it should be noted that the involvement of caspase-8 in ER-stress-mediated cell death remains controversial. In any case, these observations indicate that seeking to elevate the effects of INNO-406 on the expression and activation of $\mathrm{BH} 3-$ only proteins, such as Bim or Bad, by using other $\mathrm{BH} 3-$ only protein-stimulating agents is unlikely to be an effective strategy.

Next, we examined the effect of co-treatment with ABT-737 and INNO-406. ABT-737 dramatically augmented the killing of CML-derived cell lines by INNO-406. Moreover, co-treatment with ABT-737 was able to overcome the resistance to INNO406-induced cell death that was caused by the abrogation of the intrinsic apoptotic pathway, caused either by Bcl-2 overexpression or Bim knockdown. Although the mechanism has not been fully elucidated, Mcl-1 might have important role in the combination of INNO-406 and ABT-737. ${ }^{19,34}$ This combination effect could be explained by the neutralization of Mcl-1 by Bim, which was not only induced by INNO-406 but also dissociated from Bim/Bcl-2 complex by ABT-737. ${ }^{19,34}$ Indeed, the combination effect was largely abrogated in $\mathrm{Mcl}-1$ highly expressing MYL-R (Supplementary Figure 3a, c). Collectively, these results suggest the involvement of Mcl-1 in determining the sensitivity for the combination therapy of INNO-406 and ABT-737.

Remarkably, ABT-737 potently sensitized cells bearing the E255K or H396P Bcr-Abl point mutations to INNO-406induced apoptosis, such that they were killed as efficiently as INNO-406-treated cells bearing the wt Bcr-Abl protein. Imatinib in combination with ABT-737 did not achieve this effect (unpublished data). However, ABT-737 did not sensitize cells with the T315I-bearing Bcr-Abl protein to INNO-406induced cell death, which indicates that ABT-737 can act synergistically only when its partner agent retains at least 
some activity against target cells. On the basis of these results, we examined the effect of treating $\mathrm{Bcr}-\mathrm{Abl}^{+}$leukemias with both 17-AAG and ABT-737. We were interested in particular in the effect of this treatment regimen on leukemic cells with the T315I mutation, as 17-AAG has been shown to exert anti-Bcr-Abl ${ }^{+}$leukemia effects regardless of the $\mathrm{Abl}$ point mutation status. ${ }^{35}$ Although 17-AAG killed leukemic cells expressing wt Bcr-Abl less potently than INNO-406, its effects were markedly augmented by ABT-737; moreover, the co-treatment efficiently killed cells with the E255K, H369P and even the T315I point mutations (Figure 7). These observations confirm that dual targeting of Bcr-Abl and antiapoptotic $\mathrm{Bcl}-2$ proteins may be an effective strategy for treating $\mathrm{Bcr}-\mathrm{Abl}^{+}$leukemias. In addition, ABT-737 has been already demonstrated to be active against primitive leukemic stem cells (LSCs) in acute myeloid leukemias. ${ }^{19}$ Besides sensitizing to apoptosis, ABT-737 may be also expected to eradicate $\mathrm{Bcr}-\mathrm{Abl}^{+}$LSCs those may escape the killing by Bcr-Abl inhibitors. ${ }^{9,10}$

How does the dual targeting of Bcr-Abl and antiapoptotic $\mathrm{Bcl}-2$ proteins synergize in eradicating $\mathrm{Bcr}-\mathrm{Abl}^{+}$leukemias? To maintain and expand the tumor, leukemic cells need to maintain their capacity for cell proliferation, while being resistant to apoptosis in the face of cytotoxic or environmental insults. ${ }^{36}$ In $\mathrm{Ph}^{+}$leukemias, Bcr-Abl and its downstream signaling cascades promote both cell proliferation and resistance to apoptotic stimuli. The antiapoptotic Bcl-2 and $\mathrm{BCl}-\mathrm{X}_{\mathrm{L}}$ proteins can further increase apoptosis resistance of Bcr-Abl-transformed cells. ${ }^{37}$ The extent to which these two distinct, but converging, molecular pathways operate in particular leukemic cells may vary depending on the cellular context. This is shown by the differences in the responses of K562 and BV173 to INNO-406 or ABT-737. Moreover, it has been reported that coexpression of $\mathrm{Bcl}-2$, but not Ras or Myc, promoted the blastic transformation of myeloproliferative disease in Bcr-Abl transgenic mice. ${ }^{38}$ This again indicates the biological significance of the acquisition of an antiapoptotic phenotype in $\mathrm{Ph}^{+}$leukemias in addition to the oncogenic signaling by Bcr-Abl. This may help explain why blocking only the signaling cascades promoting cell proliferation does not eradicate leukemic cells, as these cells are also highly protected by an antiapoptotic molecular network (Figure 8). Consequently, the concomitant blockade of molecules involved in the latter molecular network may help to augment the therapeutic efficacies of Bcr-Abl inhibitors.

In conclusion, the therapeutic effects of Bcr-Abl inhibitors, such as INNO-406, that strongly induces and activates BH3only proteins can be significantly boosted by co-treatment with inhibitor, like ABT-737, that blocks antiapoptotic $\mathrm{Bcl}-2 / \mathrm{Bcl}-\mathrm{X}_{\mathrm{L}}$ proteins.

\section{Materials and Methods}

Cell lines, generation of subclones and reagents. K562 is an erythroleukemia, BV173 is a pre-B leukemia and MYL is a myeloid leukemia cell line; all were derived from $\mathrm{Ph}^{+} \mathrm{CML}$ patients in blast crisis phase. Long-term culture resulted in the isolation of the BV173R subclone, which is more resistant to imatinib-induced cell death than the parental BV173 cells. K562/Bcl-2 and K562/ FADD-DN were generated as described previously; both molecules were labeled with an N-terminal Flag tag, and the former inhibits the mitochondria-mediated intrinsic apoptotic pathway, whereas the latter protein inhibits death receptorinduced apoptosis. K562/shBim and BV173R BV173R/shBim cell lines were generated by using the anti-Bim shRNA construct cloned into the PSUPER vector. ${ }^{21-23,39} \mathrm{MYL}$ and its imatinib-resistant subclone MYL-R were kind gifts from Dr. Hideo Tanaka (Hiroshima University, Japan). ${ }^{28}$ We generated Ba/F3-derived murine hematopoietic cell lines transformed with wt p210-Bcr-Abl (Ba/F3/wt) or Bcr$\mathrm{Abl}$ bearing the $\mathrm{E} 255 \mathrm{~K}$ (Ba/F3/E255K), T315I (Ba/F3/T315I) or the H396P mutation $(\mathrm{Ba} / \mathrm{F} 3 / \mathrm{H} 396 \mathrm{P}){ }^{7,8}$ Murine FLCs that were retrovirally transformed with the $b c r-a b /$ gene were previously described, according to the guidelines of the Melbourne Directorate Animal Ethics Committee. ${ }^{22}$ INNO-406 was provided by Nippon Shinyaku (Kyoto, Japan). Imatinib and PS-341 were purchased from a pharmacy. 17-AAG was purchased from Calbiochem (La Jolla, CA, USA). ABT-737 was produced by Dr. Michael Andreeff. ${ }^{19}$ Low-binding pipette tips and tubes (Sorenson BioScience Inc., Salt Lake City, UT, USA) were used for handling ABT-737 throughout this study.

Quantitative RT-PCR. Total RNA was extracted by using the Micro-to-Midi Total RNA Extraction Kit (Invitrogen, San Diego, CA, USA) and subjected to reverse transcription. ${ }^{40}$.The mRNA levels of human bad, bik, bim, bmf, hrk, noxa and puma were analyzed by using the LightCycler System (Roche Diagnostics, Sandhoferstra $\beta$ e, Mannheim, Germany) with FastStart DNA Master SYBR Green I (Roche). Amplicons were validated by their melting curve and electrophoresis. The expression levels of the target mRNAs were normalized with that of the housekeeping gene $\beta$-actin. Informations on primers used are shown in Supplementary Table.

Western blotting. Protein samples were separated by SDS-PAGE and then electroblotted onto a Hybond-PDVF membrane (Amersham Biosciences, Uppsala, Sweden). The membranes were saturated with $5 \%$ (wt/vol) non-fat dry milk in PBS with $0.1 \%$ (vol/vol) Tween 20 (Sigma, Saint Luis, MO, USA). Antibodies (Abs) against $\beta$-actin (Sigma), Bcl-2 (Bcl-2-100, Upstate, Lake Placid, NY, USA), Bcl-X (Stressgen, Victoria, Canada), Bik (Santa Cruz Biotechnology, Santa Cruz, CA, USA), Bim (clone 3C5, produced by Dr. LA O'Reilly), Bad (Stressgen for human Bad, and Cell Signaling Technologies, Beverly, MA, USA, for murine Bad), Bmf (clone 9C10, Alexis, for human Bmf and clone 17A9 from Dr. LA O'Reilly for mouse Bmf), c-Abl (Santa Cruz), caspase-8 (BD Pharmingen, San Diego, CA, USA), FLAG (M2, Sigma), Mcl-1 (Santa Cruz), Noxa (Alexis Biochemicals, San Diego, CA, USA), phospho-Bad (Cell Signaling Technologies), phospho-tyrosine (Upstate) and Puma (ProSci Inc., Poway, CA, USA) were utilized. Ab detection was achieved by using horseradish peroxidase-conjugated secondary $\mathrm{Abs}$ and enhanced chemiluminescence (ECL) or ECL advance (Amersham Biosciences).

Cell death assay and DNA fragmentation assay. The incorporation of propidium iodide $(\mathrm{PI})$ was used to detect dead cells in flow cytometric analysis. The DNA fragmentation assay was performed by using the Apo Ladder kit (TAKARA, Shiga, Japan).

Caspase-8 activity. Caspase- 8 activity was measured by using the caspase-8 fluorometric assay kit (MBL, Nagoya, Japan) and Wallac Victor 2 Multi-label Counters (Perkin Elmer, Wellesley, MA). ${ }^{40}$

Combination cell killing effects with two agents from INNO-406, 17-AAG, PS-341 and ABT-737 on Bcr-Abl ${ }^{+}$leukemic cells. Cells were treated with various concentrations of INNO-406, 17-AAG, PS-341 or ABT-737 alone or the combinations of two of listed agents at various concentrations as indicated in the figures. The cell death assay was performed $48 \mathrm{~h}$ after drug treatment.

Statistical analysis. All data were analyzed with two-sided unpaired $t$-tests, and a $P=0.05$ was considered as statistically significant. Values are expressed as mean \pm S.D. of triplicate independent experiments in cell death assay, quantitative RT-PCR and the measurement for caspase-8 activity.

Acknowledgements. We are grateful to Professor Nakahata T, Drs. Heike T (Department of Pediatrics, Kyoto University), Huang DCS, Alexander W, Bouillet P, Puthalakath H, Cragg MS, Kaufmann T, Kelly PN (all WEHI) and Nakagawa $Y$ (Kyoto University) for their gifts of transgenic and knockout mice, reagents, scientific advice and technical support. This work was supported by Grants-in-Aid for Scientific Research from the Ministry of Education, Culture, Sports, Science and Technology of Japan, Japan Leukemia Research Fund and Yasuda Medical 


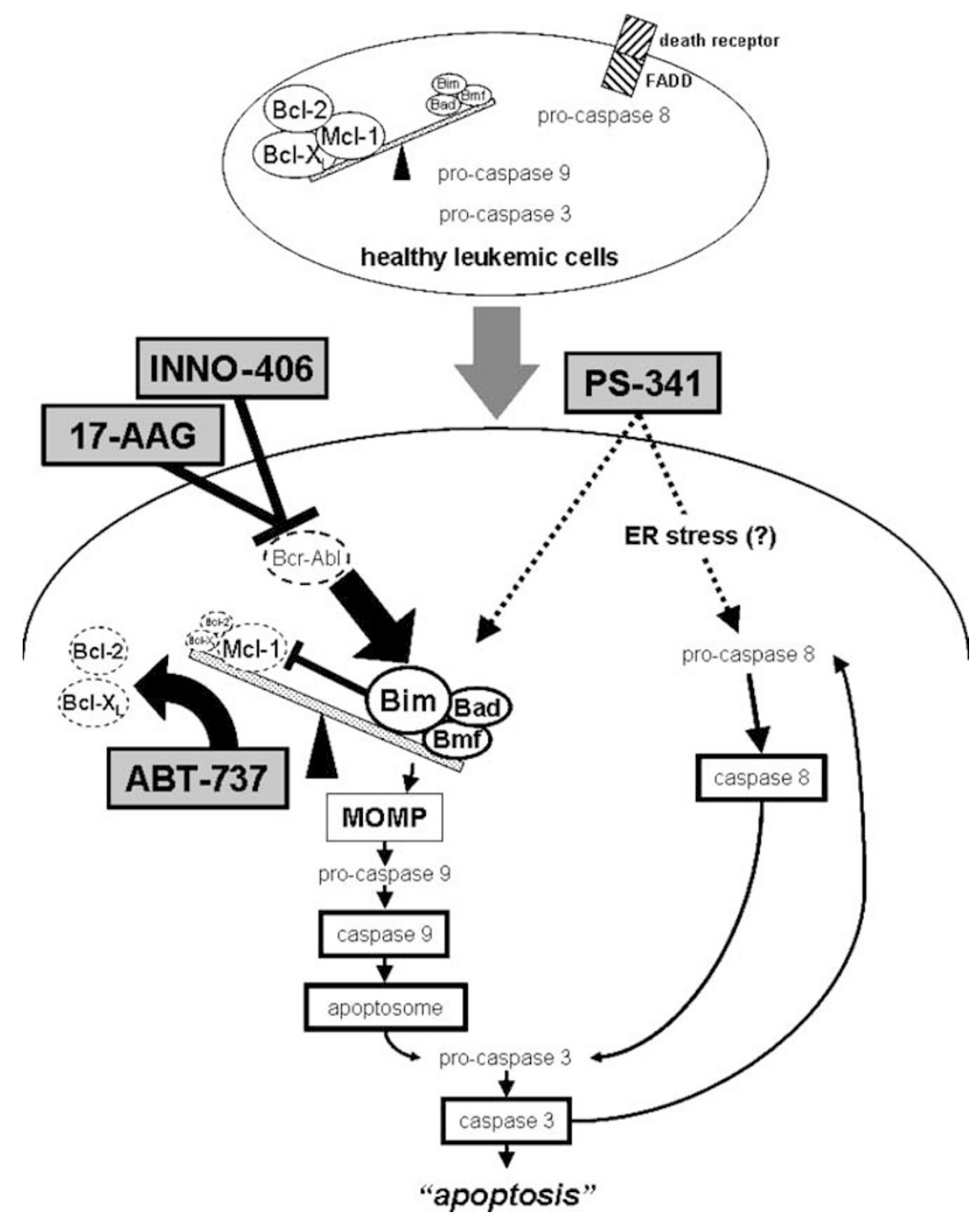

Figure 8 Cell death-inducing pathways utilized by INNO-406, PS-341, 17-AAG and ABT-737. ER, endoplasmic reticulum; MOMP, mitochondrial outer membrane permeabilization

Research Foundation (TM), the Public Trust Haraguchi Memorial Cancer Research Fund (Tokyo, Japan), Kurozumi Medical Foundation (Tokyo, Japan), Long-Term Research Grants from the TOYOBO Biotechnology Foundation (Osaka, Japan), the Uehara Memorial Biochemical Foundation (Tokyo, Japan) (JK), Grant-in-Aid of the Japan Medical Association and the Princess Takamatsu Foundation for Cancer Research (SK) and by fellowships and grants from the National Health and Medical Research Council (Australia; program no. 257502), the Leukemia and Lymphoma Society (New York; SCOR grant no. 7015) and the National Cancer Institute (NIH, US; CA 80188 and CA 43540) (AS). Supplementary information is available at Cell Death and Differentiation's website.

1. Donato NJ, Wu JY, Stapley J, Gallick G, Lin H, Arlinghaus R et al. BCR-ABL independence and LYN kinase overexpression in chronic myelogenous leukemia cells selected for resistance to STI571. Blood 2003; 101: 690-698.

2. Gorre ME, Mohammed M, Ellwood K, Hsu N, Paquette R, Rao PN et al. Clinical resistance to STI-571 cancer therapy caused by BCR-ABL gene mutation or amplification. Science 2001; 293: 876-880.

3. Mahon FX, Belloc F, Lagarde V, Chollet C, Moreau-Gaudry F, Reiffers J et al. MDR1 gene overexpression confers resistance to imatinib mesylate in leukemia cell line models. Blood 2003; 101: 2368-2373.

4. Shah NP, Nicoll JM, Nagar B, Gorre ME, Paquette RL, Kuriyan J et al. Multiple BCR-ABL kinase domain mutations confer polyclonal resistance to the tyrosine kinase inhibitor imatinib (STI571) in chronic phase and blast crisis chronic myeloid leukemia. Cancer Cell 2002; 2: 117-125.

5. Shah NP, Tran C, Lee FY, Chen $P$, Norris $D$, Sawyers $C L$. Overriding imatinib resistance with a novel ABL kinase inhibitor. Science 2004; 305: 399-401.

6. Weisberg E, Manley PW, Breitenstein W, Bruggen J, Cowan-Jacob SW, Ray A et al. Characterization of AMN107, a selective inhibitor of native and mutant Bcr-Abl. Cancer Cell 2005; 7: 129-141.

7. Kimura S, Naito H, Segawa H, Kuroda J, Yuasa T, Sato K et al. NS-187, a potent and selective dual Bcr-Abl/Lyn tyrosine kinase inhibitor, is a novel agent for imatinib-resistant leukemia. Blood 2005; 106: 3948-3954.

8. Yokota A, Kimura S, Masuda S, Ashihara E, Kuroda J, Sato K et al. INNO-406, a novel BCR-ABL/Lyn dual tyrosine kinase inhibitor, suppresses the growth of $\mathrm{Ph}^{+}$leukemia cells in the central nervous system and cyclosporine A augments its in vivo activity. Blood 2007; 109: 306-314.

9. Copland M, Hamilton A, Elrick LJ, Baird JW, Allan EK, Jordanides $\mathrm{N}$ et al. Dasatinib (BMS-354825) targets an earlier progenitor population than imatinib in primary CML but does not eliminate the quiescent fraction. Blood 2006; 107: 4532-4539.

10. Holtz MS, Slovak ML, Zhang F, Sawyers CL, Forman SJ, Bhatia R. Imatinib mesylate (ST1571) inhibits growth of primitive malignant progenitors in chronic myelogenous leukemia through reversal of abnormally increased proliferation. Blood 2002; 99: 3792-3800.

11. Komarova NL, Wodarz D. Drug resistance in cancer: principles of emergence and prevention. Proc Natl Acad Sci USA 2005; 102: 9714-9719. 
12. Michor $F$, Hughes TP, Iwasa $Y$, Branford $S$, Shah NP, Sawyers $C L$ et al. Dynamics of chronic myeloid leukemia. Nature 2005; 435: 1267-1270.

13. Huang DC, Strasser A. BH3-Only proteins-essential initiators of apoptotic cell death. Cell 2000; 103: 839-842

14. Strasser A, O'Connor L, Dixit VM. Apoptosis signaling. Annu Rev Biochem 2000; 69: 217-245

15. Aichberger KJ, Mayerhofer M, Krauth MT, Vales A, Kondo R, Derdak S et al. Low-leve expression of proapoptotic Bcl-2-interacting mediator in leukemic cells in patients with chronic myeloid leukemia: role of BCR/ABL, characterization of underlying signaling pathways, and reexpression by novel pharmacologic compounds. Cancer Res 2005; 65 9436-9444.

16. Nimmanapalli R, O'Bryan E, Kuhn D, Yamaguchi $H$, Wang $H G$, Bhalla KN. Regulation of 17-AAG-induced apoptosis: role of Bcl-2, Bcl-XL, and Bax downstream of 17-AAG mediated down-regulation of Akt, Raf-1, and Src kinases. Blood 2003; 102: 269-275.

17. Tan TT, Degenhardt K, Nelson DA, Beaudoin B, Nieves-Neira W, Bouillet $P$ et al. Key roles of BIM-driven apoptosis in epithelial tumors and rational chemotherapy. Cancer Cell 2005; 7: $227-238$

18. Zhu H, Zhang L, Dong F, Guo W, Wu S, Teraishi F et al. Bik/NBK accumulation correlates with apoptosis-induction by bortezomib (PS-341, Velcade) and other proteasome inhibitors. Oncogene 2005; 24: 4993-4999.

19. Konopleva M, Contractor R, Tsao T, Samudio I, Ruvolo PP, Kitada S et al. Mechanisms of apoptosis sensitivity and resistance to the $\mathrm{BH} 3$ mimetic $\mathrm{ABT}-737$ in acute myeloid leukemia. Cancer Cell 2006; 10: 375-388.

20. Oltersdorf T, Elmore SW, Shoemaker AR, Armstrong RC, Augeri DJ, Belli BA et al. An inhibitor of Bcl-2 family proteins induces regression of solid tumours. Nature 2005; 435 677-681.

21. Huang DC, Cory S, Strasser A. Bcl-2, Bcl-XL and adenovirus protein E1B19kD are functionally equivalent in their ability to inhibit cell death. Oncogene 1997; 14: 405-414.

22. Kuroda J, Puthalakath $\mathrm{H}$, Cragg MS, Kelly PN, Bouillet P, Huang DCS et al. Bim and Bad mediate imatinib-induced killing of $\mathrm{Bcr} / \mathrm{Abl}^{+}$leukemic cells and resistance due to their loss is overcome by a BH3 mimetic. Proc Natl Acad Sci USA 2006; 103: 14907-14912.

23. Strasser A, Harris AW, Huang DC, Krammer PH, Cory S. Bcl-2 and Fas/APO-1 regulate distinct pathways to lymphocyte apoptosis. EMBO J 1995; 14: 6136-6147.

24. Kuribara R, Honda H, Matsui H, Shinjo T, Inukai T, Sugita K et al. Roles of Bim in apoptosis of normal and Bcr-Abl-expressing hematopoietic progenitors. Mol Cell Biol 2004; 24: 6172-6183.

25. Puthalakath $\mathrm{H}$, Strasser A. Keeping killers on a tight leash: transcriptional and posttranslational control of the pro-apoptotic activity of $\mathrm{BH} 3$-only proteins. Cell Death Differ 2002; 9: 505-512

26. Seward RJ, von Haller PD, Aebersold R, Huber BT. Phosphorylation of the pro-apoptotic protein Bim in lymphocytes is associated with protection from apoptosis. Mol Immunol 2003; 39: 983-993.
27. Basso AD, Solit DB, Chiosis G, Giri B, Tsichlis $P$, Rosen N. Akt forms an intracellular complex with heat shock protein 90 (Hsp90) and $\mathrm{Cdc} 37$ and is destabilized by inhibitors of Hsp90 function. J Biol Chem 2002; 277: 39858-39866.

28. Ito $\mathrm{T}$, Tanaka H, Kimura A. Establishment and characterization of a novel imatinib-sensitive chronic myeloid leukemia cell line MYL, and an imatinib-resistant subline MYL-R showing overexpression of Lyn. Eur H Haematol 2007; 78: 417-431.

29. Cortes J, Talpaz M, O'Brien S, Jones D, Luthra R, Shan J et al. Molecular responses in patients with chronic myelogenous leukemia in chronic phase treated with imatinib mesylate. Clin Cancer Res 2005; 11: 3425-3432.

30. Press RD, Love Z, Tronnes AA, Yang R, Tran T, Mongoue-Tchokote S et al. BCR-ABL mRNA levels at and after the time of a complete cytogenetic response (CCR) predict the duration of CCR in imatinib mesylate-treated patients with CML. Blood 2006; 107: $4250-4256$.

31. Essafi A, Fernandez de Mattos S, Hassen YA, Soeiro I, Mufti GJ, Thomas NS et al. Direct transcriptional regulation of Bim by FoxO3a mediates STI571-induced apoptosis in BcrAbl-expressing cells. Oncogene 2005; 24: 2317-2329.

32. Ley R, Ewings KE, Hadfield K, Cook SJ. Regulatory phosphorylation of Bim: sorting out the ERK from the JNK. Cell Death Differ 2005; 12: 1008-1014.

33. Obeng EA, Carlson LM, Gutman DM, Harrington Jr WJ, Lee KP, Boise LH. Proteasome inhibitors induce a terminal unfolded protein response in multiple myeloma cells. Blood 2006; 107: 4907-4916.

34. van Delft MF, Wei AH, Mason KD, Vandenberg CJ, Chen L, Czabotar PE et al. The BH3 mimetic ABT-737 targets selective Bcl-2 proteins and efficiently induces apoptosis via Bak/ Bax if Mcl-1 is neutralized. Cancer Cell 2006; 10: 389-399.

35. Gorre ME, Ellwood-Yen K, Chiosis G, Rosen N, Sawyers CL. BCR-ABL point mutants isolated from patients with imatinib mesylate-resistant chronic myeloid leukemia remain sensitive to inhibitors of the BCR-ABL chaperone heat shock protein 90. Blood 2002; 100: 3041-3044.

36. Letai A, Sorcinelli MD, Beard C, Korsmeyer SJ. Antiapoptotic BCL-2 is required for maintenance of a model leukemia. Cancer Cell 2004; 6: 241-249.

37. Cirinna M, Trotta R, Salomoni P, Kossev P, Wasik M, Perrotti D et al. Bcl-2 expression restores the leukemogenic potential of a BCR/ABL mutant defective in transformation. Blood 2000; 96: 3915-3921.

38. Jaiswal S, Traver D, Miyamoto T, Akashi K, Lagasse E, Weissman IL. Expression of BCR/ $\mathrm{ABL}$ and $\mathrm{BCL}-2$ in myeloid progenitors leads to myeloid leukemias. Proc Natl Acad Sci USA 2003; 100: 10002-10007.

39. Bouillet P, Robati M, Bath M, Strasser A. Polycystic kidney disease prevented by transgenic RNA interference. Cell Death Differ 2005; 12: 831-833.

40. Kuroda J, Kimura S, Segawa H, Sato K, Matsumoto S, Nogawa M et al. p53-independent anti-tumor effects of the nitrogen-containing bisphosphonate zoledronic acid. Cancer Sci 2004; 95: 186-192.

Supplementary Information accompanies the paper on Cell Death and Differentiation website (http://www.nature.com/cdd) 